\title{
Sosialisasi Kenyamanan Termal pada Bangunan Rumah Tinggal di Kawasan Permukiman Sungai Cikoang Kabupaten Takalar
}

\author{
Nurul Jamala ${ }^{1 *}$, Ramli Rahim ${ }^{1}$, Baharuddin Hamzah ${ }^{1}$, Syavir Latif ${ }^{1}$, Idawarni Asmal ${ }^{1}$, Samsuddin \\ Amin $^{1}$, Rosady Mulyadi ${ }^{1}$, Asniawaty Kusno ${ }^{1}$, Syahriana Syam ${ }^{1}$, Pratiwi Mushar ${ }^{1}$ \\ Departemen Arsitektur, Fakultas Teknik, Universitas Hasanuddin \\ nuruljamala@yahoo.co.id*
}

\begin{abstract}
Abstrak
Kegiatan Pengabdian Masyarakat dilakukan di Kabupaten Takalar Kecamatan Mangarabombang Desa Cikoang dengan judul "Sosialisasi Kenyamanan Termal pada Bangunan Rumah Tinggal di Kawasan Permukiman Tepi Air Cikoang Kabupaten Takalar”. Pertambahan jumlah penduduk semakin meningkat dan kebutuhan Rumah tinggal sebagai kebutuhan utama masyarakat pun semakin meningkat. Kawasan permukiman di tepi air cikoang, perlu mendapatkan perhatian, khususnya aspek kenyamanan termal. Pada area pesisir pantai mempunyai kondisi udara yang berfluktuasi, sehingga faktor utama yang perlu diperhatikan adalah kenyamanan termal dalam beraktifitas di dalam rumah tinggal. Setelah sosialisasi dilaksanakan, diharapkan masyarakat dapat memahami dan menerapkan teori dan saran demi terciptanya kenyamanan termal pada rumah tinggal masyarakat di pesisir sungai Cikoang. Kegiatan pengabdian dilanjutkan dengan menganalisis secara langsung beberapa unit hunian pada area pesisir sungai Cikoang. Selanjutya disarankan kepada masyarakat, apabila akan membangun atau memperbaiki rumah tinggal di area pesisir, sebaiknya masyarakat memperhatikan kenyamanan termal pada lingkungan sekitarnya dan kenyamanan termal pada rumah tinggal mereka yang sesuai dengan standar.
\end{abstract}

Kata Kunci: Kenyamanan; Termal; Pesisir; Permukiman; Sosialisasi.

\begin{abstract}
Community dedication were carried out in Takalar Regency, Mangarabombang District, Cikoang Village with the title "Socialization of Thermal Comfort in Residential Buildings in the Coastal Settlement Area of Cikoang, Takalar Regency". Population growth is increasing and the need for housing as the main need of the community is increasing. Residential areas on the edge of the air, need attention, especially the comfort of thermal comfort. In coastal areas that have fluctuating air conditions, the main factor that needs to be considered is the thermal comfort in activities in the house. After the socialization is carried out, it is hoped that the community will be able to understand the theory in order to create thermal comfort in community residences on the coast of the Cikoang river. Community service activities directly analyze several residential units in the coastal area of the Cikoang river. Furthermore, in accordance with the needs of the community, the blessing will build or repair houses in coastal areas, both people who pay attention to the thermal comfort of the surrounding environment and the thermal comfort of their homes that are adjusted to standards.
\end{abstract}

Keyword: Comfort; Thermal; Coastal; Settlement; Sozialization.

\section{Pendahuluan}

Kabupaten Takalar terletak di Propinsi Sulawesi Selatan. Terdapat sembilan Kecamatan yaitu Polombangkeng Selatan, Pattallassang, Polombangkeng Utara, Galesong, Galesong Selatan, Galesong Utara, Sanrobone, Mappakasunggu dan Manggarabombang. Kabupaten Takalar memiliki luas wilayah 566,52 km2 dengan jumlah penduduk sebanyak \pm 250.000 jiwa. Di kabupaten Takalar terdapat Desa Cikoang yang terletak di pesisir selatan Kecamatan Manggarabombang. Kondisi Desa Cikoang merupakan daerah beriklim tropis, oleh karena terletak pada pesisir Sungai Cikoang. Luas wilayah Desa Cikoang sebesar 555,49 Ha dan merupakan dataran rendah pada ketinggian 50 meter diatas permukaan laut. Desa Cikoang berjarak $\pm 8 \mathrm{~km}$ dari Kecamatan Manggarabombang dan $\pm 15 \mathrm{~km}$ dari Kabupaten Takalar. 
Garis sempadan Sungai Cikoang adalah salah satu icon dari Desa Cikoang dan merupakan gerbang masuk menuju Desa Cikoang, dengan lebar Sungai yaitu $\pm 70-100$ meter. Sebagai pertemuan dari Sungai Cikoang dan laut yang merupakan Selat Makassar menjadikan air yang berada di Sungai ini merupakan air payau. Menurut Permen PU dan Perumahan Rakyat Republik Indonesia tentang Penetapan Garis Sempadan Sungai dan Garis Sempadan Danau bahwa garis sempadan Sungai besar tidak bertanggul di luar kawasan perkotaan ditentukan paling sedikit berjarak 100 (seratus) meter dari tepi kiri dan kanan sepanjang alur Sungai (Permen PU, 2001).

Kondisi iklim wilayah Kabupaten Takalar dan sekitarnya secara umum ditandai dengan jumlah hari hujan \& curah hujan yang relatif tinggi. Suhu udara minimum rata-rata $22,2^{\circ} \mathrm{C}-30,4^{0} \mathrm{C}$ pada bulan Februari - Agustus dan suhu udara maksimum mencapai $30,5^{\circ} \mathrm{C}-33,9^{\circ} \mathrm{C}$ pada bulan September - Januari. Secara hidrologis Kabupaten Takalar beriklim tropis dengan dua musim, yaitu musim hujan dan musim kemarau. Pada dasarnya angin musim di Kabupaten Takalar dipengaruhi oleh letak geografis wilayah yang merupakan pertemuan Selat Makassar \& Laut Flores. Kondisi ini berdampak pada putaran angin yang dapat berubah setiap waktu, hal ini terjadi pula pada Desa Cikoang Kecamatan Manggarabombang.

Salah satu faktor yang perlu diperhatikan dalam unit hunian yaitu sistem penghawaan yang cukup di dalam ruangan. Faktor ini, sangat penting dipikirkan agar tercipta kenyamanan bagi pengguna ruang dalam melakukan aktifitas. Selain itu, memiliki penghawaan alami yang cukup baik sehingga dapat menghemat penggunaaan energi listrik, oleh karena tidak tergantung pada penghawaan buatan. Memanfaatkan angin sebagai sumber penghawaan alami dalam rumah tinggal, merupakan pemanfaaatan potensi energi alam.

Tercapainya kenyamanan termal bukan hanya pada unit hunian, namun perlu diperhatikan bagaimana kondisi lingkungannya, begitupun pada pada lingkungan pesisir Sungai Cikoang yang memiliki temperatur dan kecepatan angin yang relatif tinggi. Terdapat sejumlah rumah di kawasan permukiman pesisir Sungai Cikoang, yang cenderung berorientasi ke Sungai, oleh karena mata pecaharian masyarakat adalah sebagai nelayan. Terdapat pula sejumlah rumah juga yang berorientasi membelakangi Sungai sehingga lebih berpotensi untuk mencemari lingkungan, oleh karena buangan sampah padat maupun limbah cair akan lebih mudah terbuang ke Sungai. Beberapa faktor yang perlu diperhatikan ini, sehingga perlu melakukan pengabdian masyarakat, terkait dengan kenyamanan termal pada kawasan permukiman Sungai Cikoang.

\section{Latar Belakang Teori}

Perkembangan pemukiman baik di pusat kota ataupun pinggiran kota semakin berkembang sesuai dengan kebutuhan hidup manusia. Dalam memenuhi kebutuhannya, manusia cenderung berusaha secara maksimal menyanggupi seluruh kebutuhan hidupnya. Salah satu kebutuhan dasar manusia adalah rumah yang difungsikan sebagai wadah untuk berlindung dalam melakukan aktifitasnya. Rumah adalah penjelmaan eksistensi manusia yang tidak statis, melainkan selalu berkembang sesuai potensi yang dimiliki. Rumah atau perumahan adalah sebagai suatu proses dalam kehidupan manusia (Silas, 1983).

Tiga hal yang perlu dipenuhi dalam program pembangunan perumahan dan pemukiman yaitu: (1) Terpenuhinya salah satu kebutuhan dasar manusia dalam upaya meningkatkan kwalitas kesejahteraan pemenuhan kebutuhan kehidupan sosial dan upayanya; (2) Memberikan implikasi dibidang ekonomi dimana pembangunan perumahan dan pemukiman mendorong aktifitas 
ekonomi; dan (3) Pembangunan perumahan dan pemukiman merupakan bagian dari implementasi fisik perencanaan tata ruang wilayah.

Aspek yg mempengaruhi rumah tinggal di Kawasan permukiman pesisir adalah radiasi matahari, angin, temperature. Orientasi bangunan sebaiknya utara selatan agar radiasi matahari tidak langsung masuk ke dalam bangunan, oleh karena dapat menimbulkan suhu panas. Cahaya matahari dapat masuk ke dalam bangunan melalui bukaan jendela, lubang udara dan pintu. Bukaan ideal mencapai 40-80\% luas keseluruhan dinding atau 10-20\% luas keseluruhan lantai. Prinsip dasar penghawaan alami utuk pendinginan pasif bangunan antara lain: Ventilasi alami; terjadi karena perbedaan tekanan udara dan suhu/temperature, Aliran udara dan arah angin, Orientasi bangunan, Kontrol ventilasi dan Model penghawaan alami.

Konsep dasar perencanaan bangunan antara lain: (a) Bersifat alamiah (natural) dimana cahaya alami memiliki nilai-nilai baik fisik maupun spriritual yg tak tergantikan oleh cahaya buatan; (b) Tersedia berlimpah, gratis \& terbaharui; (c) Memiliki daya panas dan kimiawi yg diperlukan bagi mahluk hidup di bumi; dan (c) Rancangan arsitektur bangunan menjadi sangat penting untuk mengubah potensi negatif energi surya menjadi potensi positif yaitu memanfaatkan secara maksimal (BSN, 2001).

Menurut Satwiko (2005) bahwa persyaratan sistem penghawaan yang baik sebagai berikut: (1) Suhu udara luar sebaiknya dibawah $28^{\circ} \mathrm{C}$; (2) kualitas udara yang baik yaitu tidak berbau, berdebu dan tidak mengandung zat polutan lain; (3) tidak menimbulkan kebisingan; (4) rumah yang berdiri sendiri dan tidak berdempetan dengan rumah lainnya; (5) permukaan bangunan yang terlindung dari panas udara secara langsung; (6) ventilasi silang didalam bangunan; (7) jarak yang cukup antara jendela dan bangunan atau penghalang di depannya; (8) lebar jendela minimal dua buah pada bidanf yang tidak sama; dan (9) ) terdapat pohon atau penghijauan di lingkungan sekitarnya.

Pemerintah telah menuangkan dalam peraturan perundangan yang mengutarakan bahwa rumah adalah bangunan yang berfungsi sebagai tempat tinggal atau hunian dan sarana pembinaan keluarga (Undang Undang Republik Indonesia, 1992). Selanjutnya Perumahan adalah kelompok rumah yang berfungsi sebagai lingkungan tempal tinggal atau lingkungan hunian yang dilengkapi dengan prasarana dan sarana lingkungan. Tiga hal yang perlu dipenuhi dalam program pembangunan perumahan dan pemukiman yaitu: (1) Terpenuhinya salah satu kebutuhan dasar manusia dalam upaya meningkatkan kwalitas kesejahteraan pemenuhan kebutuhan kehidupan sosial dan upayanya; (2) Memberikan implikasi dibidang ekonomi dimana pembangunan perumahan dan pemukiman mendorong aktifitas ekonomi; dan (3) Pembangunan perumahan dan pemukiman merupakan bagian dari implementasi fisik perencanaan tata ruang wilayah.

\section{Metode Untuk Menangani Permasalahan}

Tahapan Sosialisasi kenyamanan termal pada bangunan rumah tinggal di Kawasan permukiman Sungai Cikoang Kabupaten Takalar sebagai berikut:

a. Melakukan survey lapangan pada beberapa bangunan rumah tinggal yang terletak di pesisir Sungai Cikoang.

b. Menganalisis rumah panggung yang terletak di kawasan permukiman Sungai Cikoang dan yang terletak di sekitar jembatan Sungai Cikoang 
c. Mengadakan penyuluhan di Kantor Desa Cikoang yang dihadiri oleh staf pegawai kantor Desa Cikoang sebagai wakil dari masyarakat di Desa Cikoang, yang diharapkan selanjutnya akan mengadakan penyuluhan langsung pada sekelompok masyarakat yang menetap di pesisir Sungai Cikoang.

Lokasi pengabdian masyarakat di Kantor Desa Cikoang Kecamatan Mangarabombang. Di Desa tersebut terdapat Dusun Cikoang yang terletak pada pesisir Sungai Cikoang, seperti pada peta berikut ini (Gambar 1). Disepanjang pesisir Sungai Cikoang terdapat rumah tinggal berbentuk rumah panggung. Pada area pesisir ini, juga terdapat pepohonan yang sangat berfungsi bagi rumah tinggal disekitarnya, dengan pertimbangan kecepatan angin dipermukaan sepanjang pesisir, dapat dihalangi oleh Pohon tersebut dan terkait pula dengan suhu dan kelembaban (gambar 1).

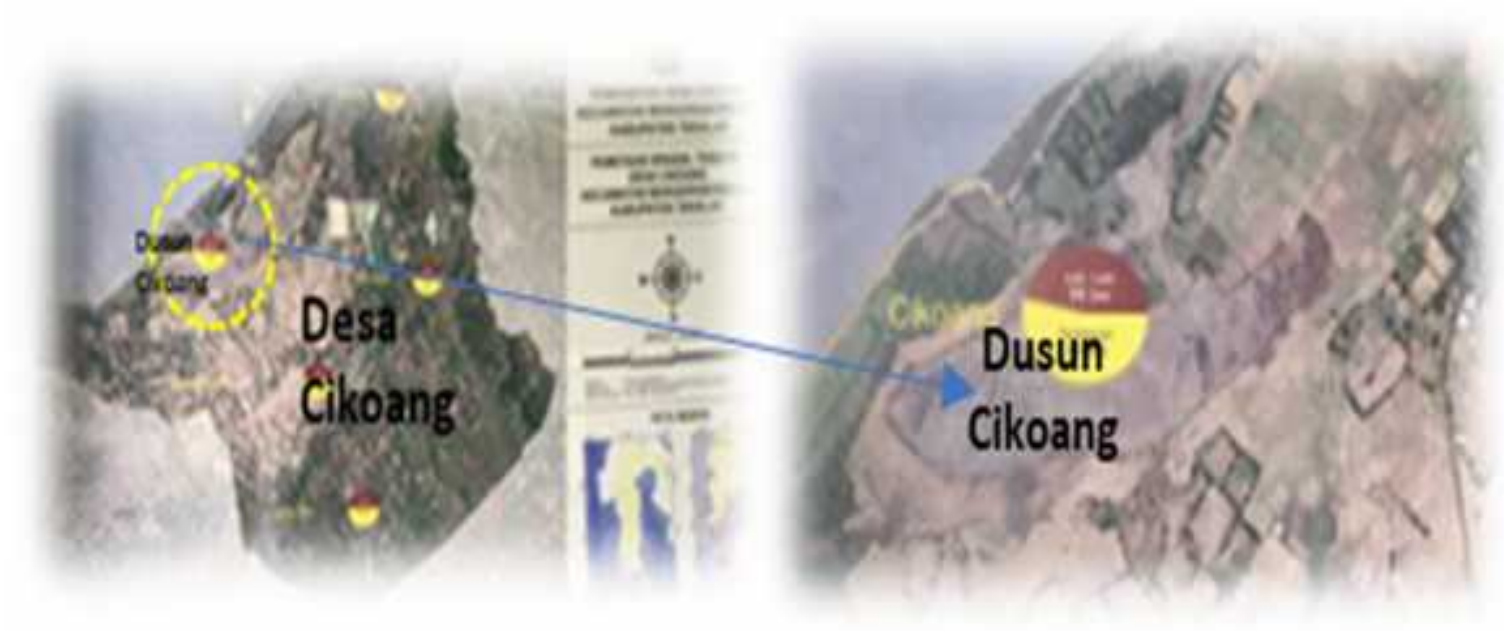

Gambar 1. Peta Desa Cikoang dan Dusun Cikoang

Desa Cikoang terdiri dari 5 Dusun yaitu Dusun Parang, Jonggo, Bila-Bilaya, Cikoang dan Bonto Baru. Lokasi yang terpilih dalam pelaksanaan sosialisasi pengabdian makayakat pada Kawasan pesisir yaitu Dusun Cikoang. Jumlah Penduduk Dusun Cikoang sebanyak 649 orang dengan jumlah lak-laki sebanyak 305 orang dan perempuan sebanyak 344 orang. Oleh karena kawasan Dusun Cikoang berhubungan langsung dengan Sungai Cikoang, sehingga banyak penduduk yg menetap pada rumah tinggal di area pesisir Sungai Cikoang (Gambar 2). 


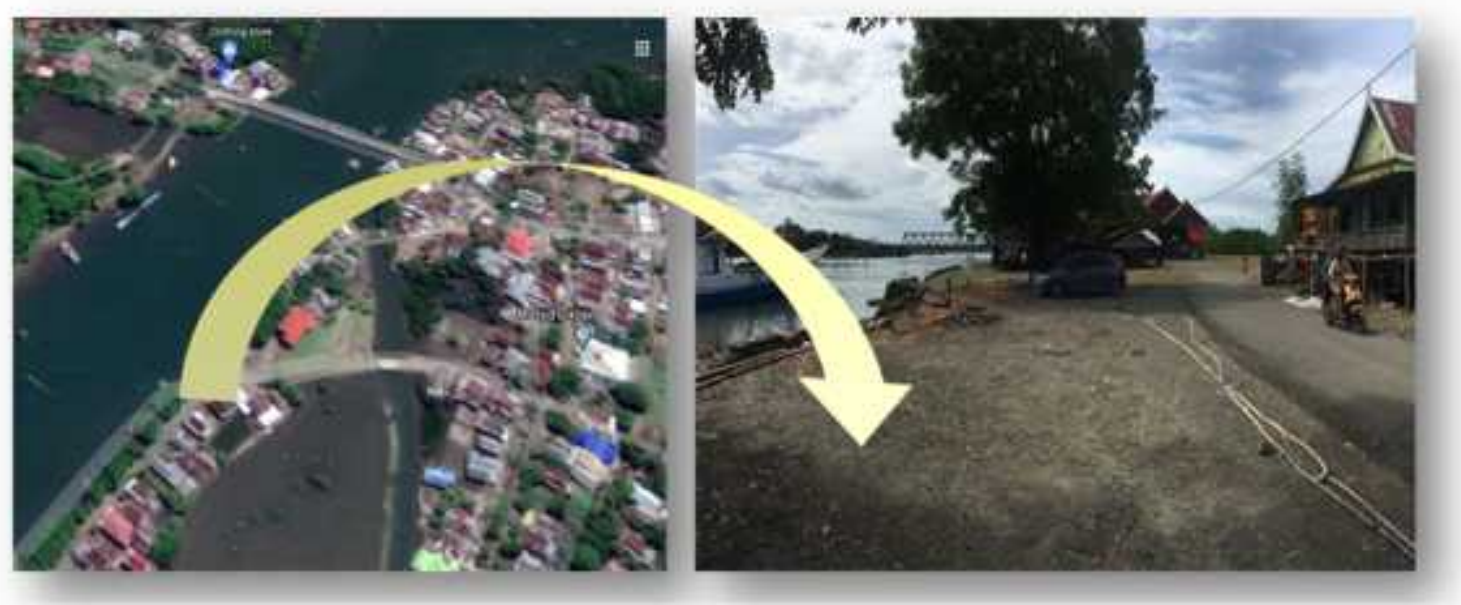

Gambar 2. Peta Lokasi Pesisir Pantai Cikoang

Pemilihan obyek unit hunian di Dusun Cikoang yaitu 2 unit rumah panggung yang terletak pada Kawasan pesisir Sungai Cikoang dan sejumlah rumah panggung di sekitar jembatan Sungai Cikoang (Gambar 3).
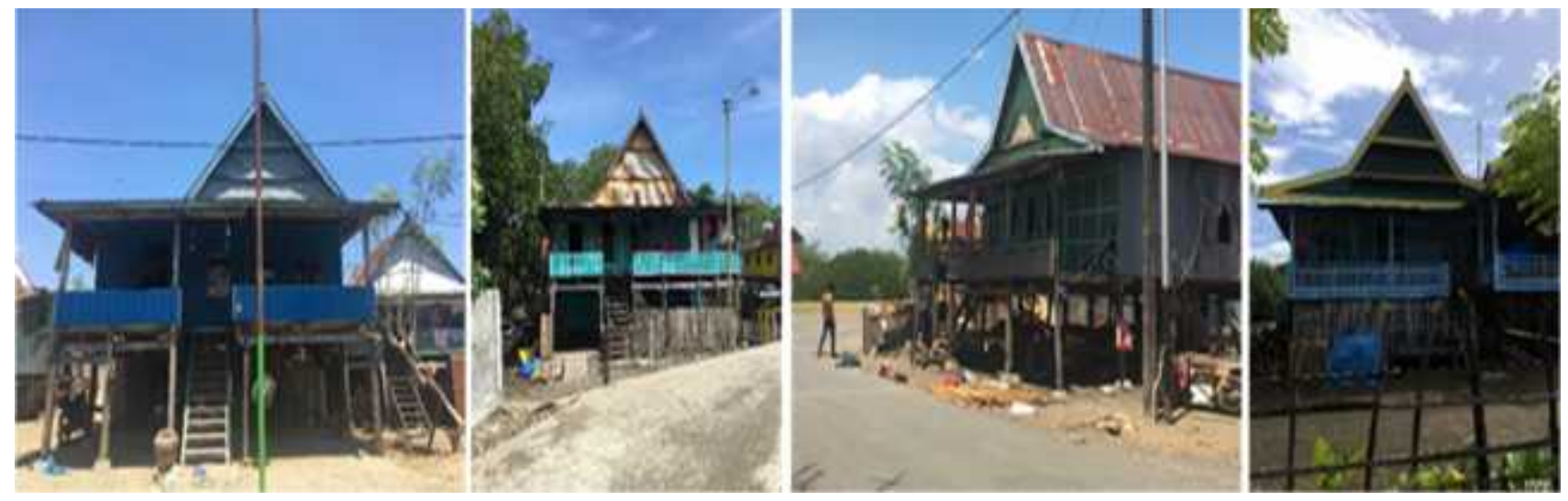

Gambar 3. Obyek rumah tinggal di Permukiman Pesisir Pantai Cikoang

Target luaran setelah terlaksananya kegiatan Sosialisasi pengabdian masyarakat ini, diharapkan masyarakat dapat memahami prinsip dasar kenyamanan termal pada rumah tinggal yang berada di kawasan pesisir. selanjutnya diharapkan pula, bahwa masyarakat akan menerapkan acuan ini demi terciptanya kenyamanan termal pada rumah tinggal dan lingkungan permukiman di sepanjang Sungai Cikoang, khususnya masyarakat yang bertempat tinggal di Dusun Cikoang.

Sosialisasi dilaksanakan dengan menjelaskan tentang kondisi termal yang harus diperhatikan pada lingkungan permukiman pesisir, khususnya pada lingkungan rumah tinggal masyarakat di Dusun Cikoang. Selain itu, memberikan buku pedoman sebagai panduan untuk menciptakan kenyamanan termal dalam rumah tinggal masyarakat di sepanjang Sungai Cikoang. 


\section{Hasil dan Diskusi}

Pengabdian Masyarakat adalah "Sosialisasi kenyamanan Termal pada Bangunan Rumah Tinggal di Kawasan Permukiman Sungai Cikoang Kabupaten Takalar". Sosialisasi tidak dapat dilakukan secara langsung pada masyarakat di Dusun Cikoang, oleh karena kondisi pandemi Covid-19 yang tidak memungkinkan berkumpul bersama masyarakat setempat.

Sosialisasi (Gambar 4 dan Gambar 5) dilakukan di kantor Desa Cikoang yang dihadiri oleh Kepala Desa beserta seluruh pegawai kantor Desa Cikoang. Kegiatan sosialisasi ini, akan ditindak lanjutkan oleh para pegawai, dengan menjelaskan secara langsung pada sekelompok masyarakat untuk menciptakan kenyamanan termal pada kawasan rumah tinggal masyarakat di pesisir Sungai Cikoang.
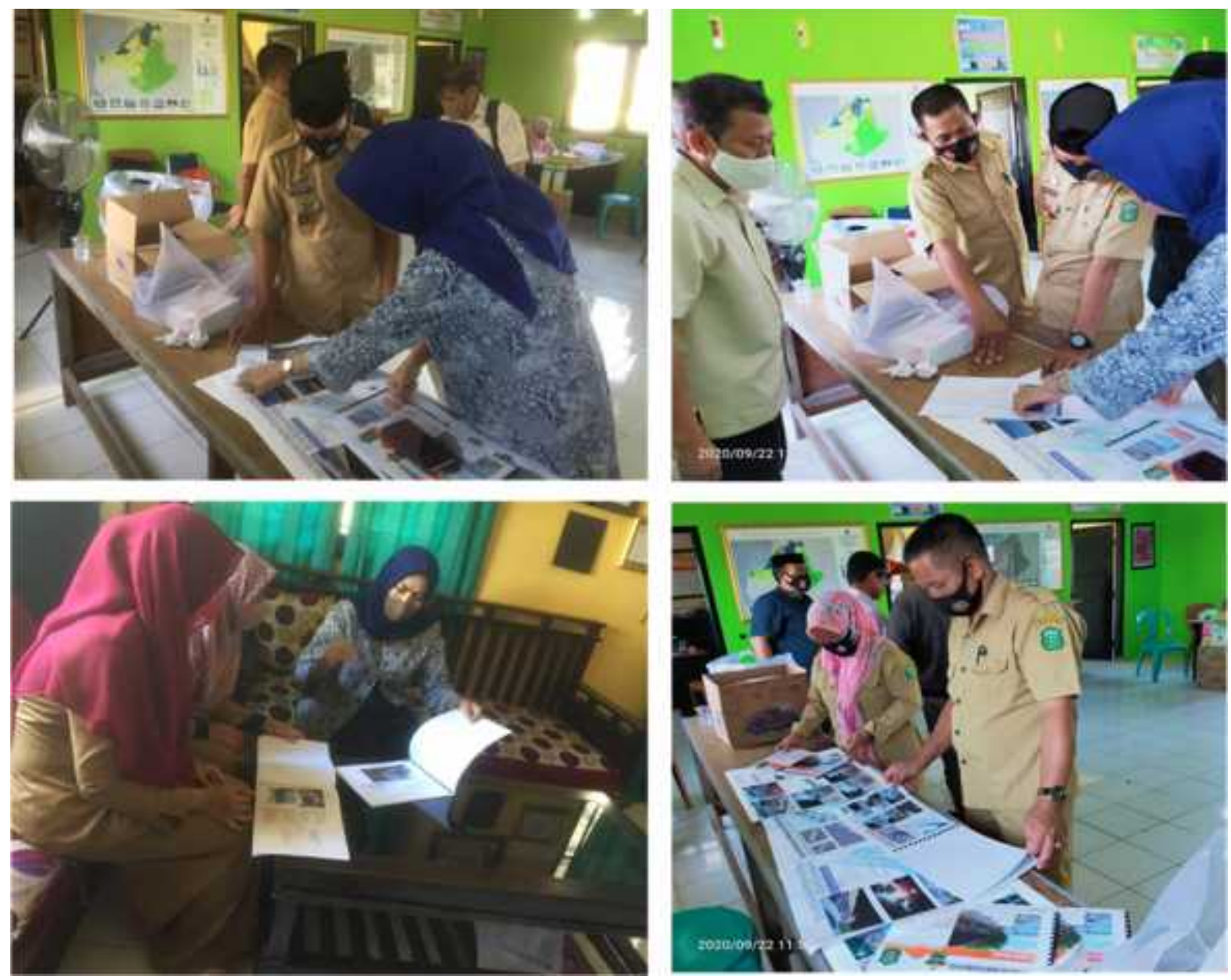

Gambar 4. Sosialisasi pengabdian masyarakat di Kantor Desa Cikoang 

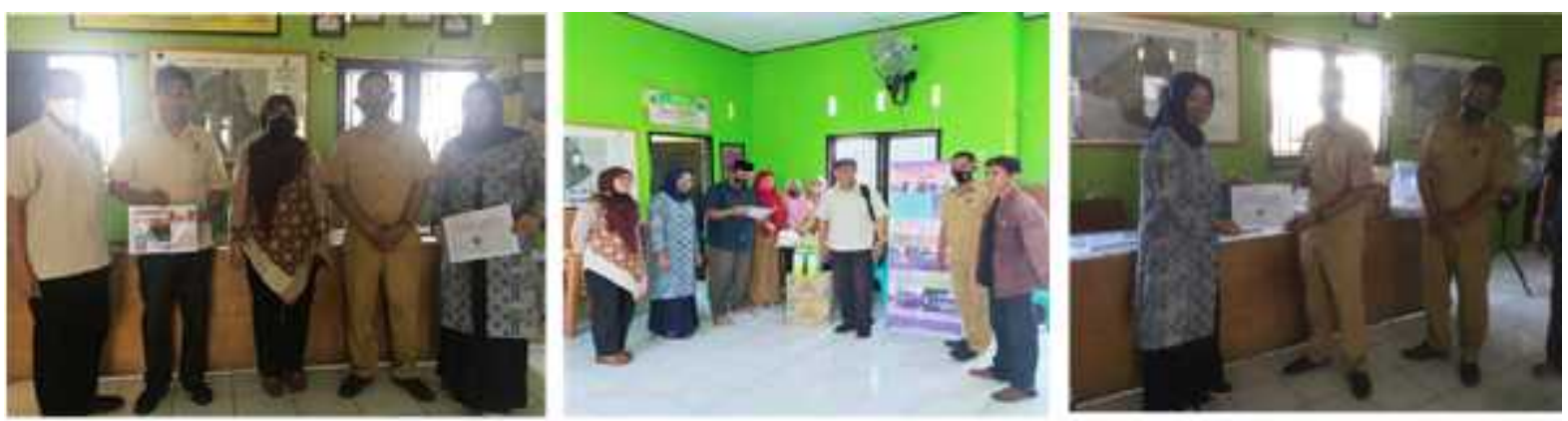

Gambar 5. Penyerahan buku panduan bagi masyarakat di Desa Cikoang

Sosialisasi ini mengungkapkan beberapa teori dasar dan contoh sederhana tentang pemanfaatan penghawaan alami pada rumah tinggal di pesisir Sungai Cikoang. Kegiatan ini dilanjutkan dengan melakukan kunjungan pada beberapa rumah tinggal di Dusun Cikoang yang terletak di Desa Cikoang Kecamatan Manggarabombang.

Kondisi lokasi permukiman di pesisir Sungai Cikoang (Gambar 6). Sebelum acara sosialisasi, dilakukan survey pada permukiman di pesisir Sungai Cikoang, untuk mengetahui bagaimana kondisi termal pada lingkungan permukiman tersebut. Hasil survey menunjukkan beberapa hal menjadi pertimbangan pada rumah tinggal di area pesisir Sungai Cikoang.
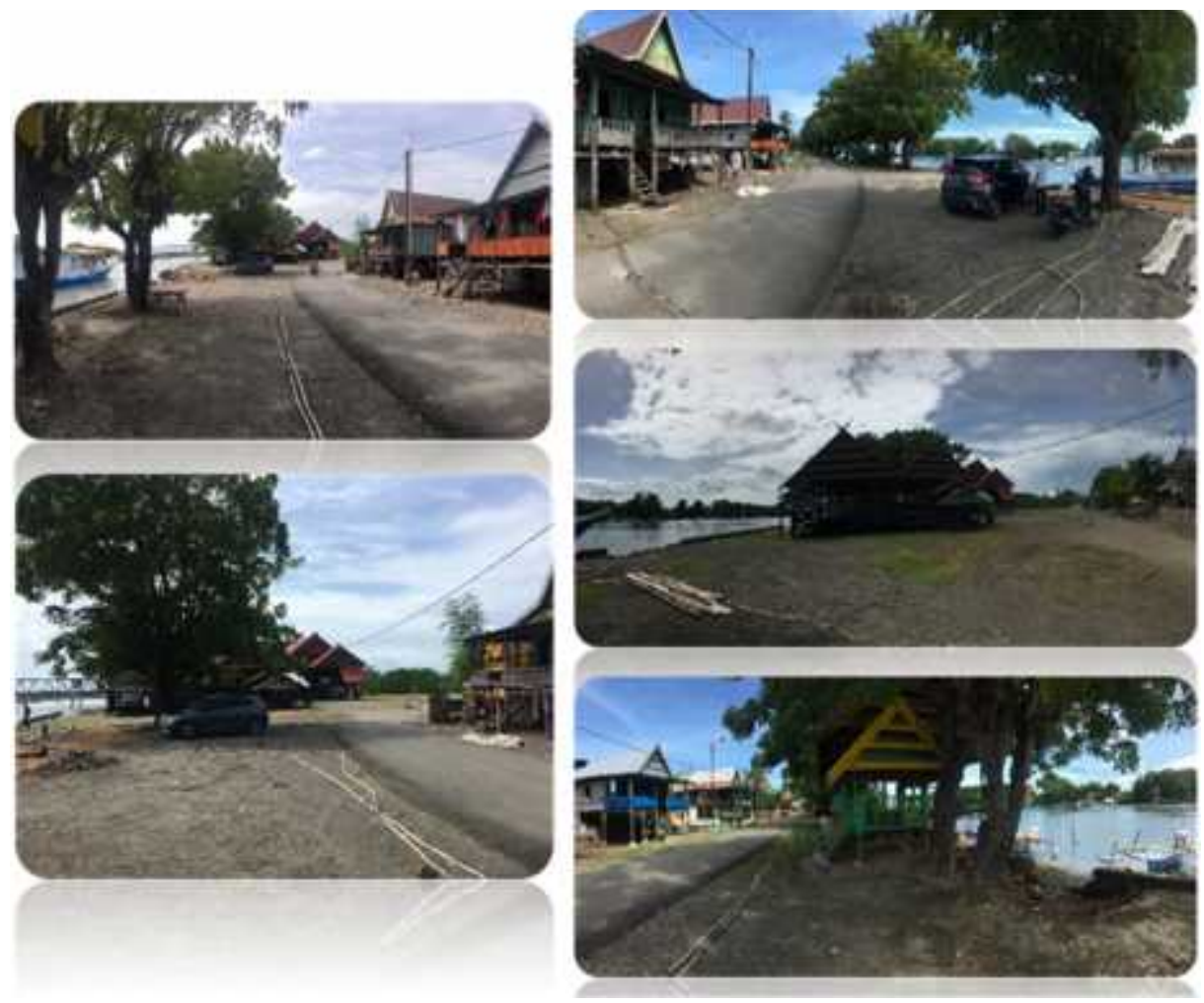

Gambar 6. Kondisi lokasi Permukiman di Pesisir Pantai Cikoang 
Selanjutnya menganalisis kondisi unit hunian berupa rumah panggung yang terletak di kawasan pesisir Sungai Cikoang.

\subsection{Analisis Kondisi Rumah Panggung (RP-1)}

Rumah panggung merupakan salah satu fitur arsitektur vernacular di Indonesia. Rumah panggung pada kawasan pesisir Sungai Cikoang, merupakan tempat tinggal masyarakat dengan mata pencaharian sebagai nelayan. Di sepanjang pesisir Sungai di Dusun Cikoang, terdapat sejumlah rumah di sepanjang Sungai Cikoang dengan berbagai bentuk rumah panggung. Pada Kawasan ini, tim peneliti menjadikan salah satu obyek yang akan dianalisis yaitu rumah panggung yang berbatasan langsung dengan Sungai Cikoang (gambar 7).

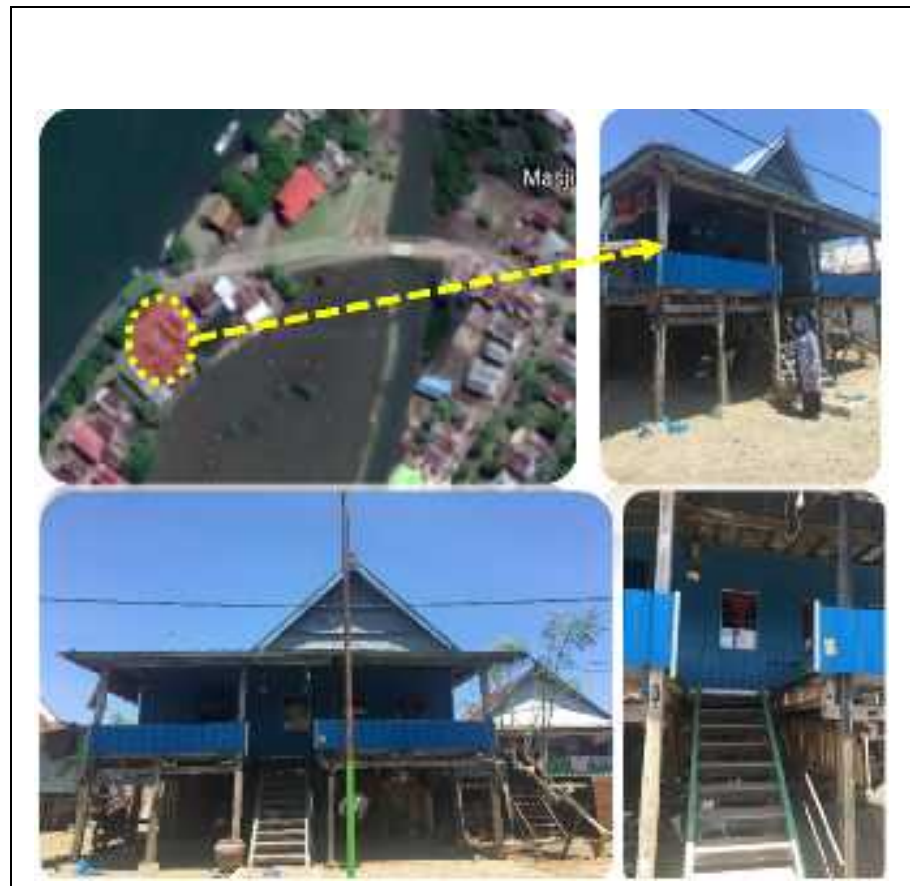

Gambar 7. Kondisi Rumah Panggung (RP-1)

\section{Kondisi Bangunan dan Lingkungan}

$\square$ Pada area sekeliling rumah tidak terdapat penghijauan berupa pohon rindang, sehingga kecepatan angin sangat berpengaruh terhadap posisi rumah yang terletak pada area pesisir.

- Orientasi bangunan ke arah Barat Laut. Di sore hari cahaya matahari terbenam di arah Barat, sehingga temperature relative meningkat pada siang hingga sore hari.
Suasana lingkungan permukiman dapat dipersepsikan nyaman, namun pada kondisi tertentu terjadi temperature dan kecepatan angin yang relative tinggi, oleh karena terletak di pesisir sungai Cikoang

Jarak antara rumah tinggal cukup jauh, sehingga sirkulasi udara dipersepsikan baik.

Kondisi temperatur di dalam rumah ini, dapat dipersepsikan nyaman, oleh karena udara panas dan kecepatan angin tidak langsung masuk ke dalam rumah. Rumah ini mempunyai teras depan, sehingga dapat terlindungi dari tempertur tinggi.

Terdapat bukaan jendela dan ventilasi pada bagian depan bangunan, namun tidak terjadi sirkulasi udara yang baik di dalam rumah, oleh karena tidak terjadi silang sirkulasi udara di dalam rumah ini.

$\square$ Kehadiran aliran air (sungai) juga dapat menurunkan suhu pada permukaan di sekitar bangunan 


\subsection{Analisis Kondisi Rumah Panggung (RP-2)}

Kondisi bangunan dan lingkungan pada Kawasan pesisir Sungai Cikoang, mempuyai temperatur yang relatif tinggi, sehingga perlu diperhatikan kenyamanan termal di dalam rumah. Beberapa alternatif yang dapat diterapkan pada Kawasan ini, antara lain menata penghijauan di sekitar rumah, bukaan jendela dan ventilasi ditempatkan dengan baik. Hal lain yang perlu diperhatikan adalah fungsi kolong di bagian bawah rumah tidak difungsikan secara keseluruhan, dengan pertimbangan sirkulasi suhu udara di dalam rumah. Rumah panggung sebagai obyek kedua ini, terletak di pesisir Sungai Cikoang (Gambar 8).

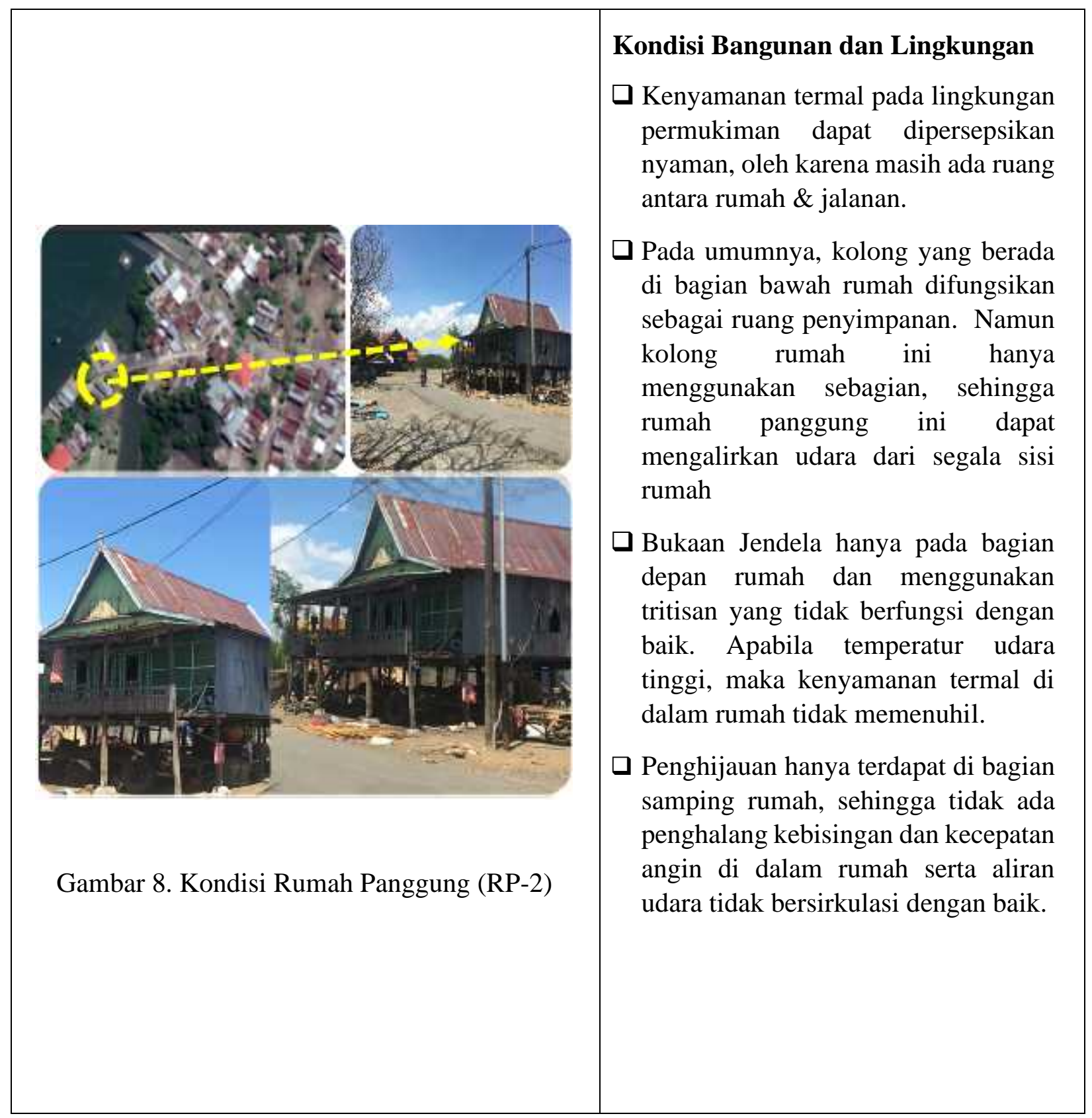




\subsection{Analisis Kondisi Lingkungan Pesisir (LP-1)}

Wilayah pesisir Dusun Cikoang merupakan daerah peralihan antara sungai dan daratan. Di dusun Cikoang terdapat jembatan diatas Sungai Cikoang, untuk memudahkan masyarakat menuju lokasi di seberang sungai. Di sekitar jembatan terdapat beberapa rumah pangung sebagai tempat tinggal masyarakat Dusun Cikoang. Untuk menyelamatkan kebersihan Sungai Cikoang terhadap sampah, limbah cair dan lainnya, diharapkan perilaku seluruh masyarakat dapat bekerja sama unutk menghindari kerusakan lingkungan. Selain kebersihan lingkungan, perlu diperhatikan kenyamanan termal pada lingkungan yaitu dengan menata vegetasi berupa pepohonan rindang yang dapat mengatur kecepatan angin, suhu dan kelembaban (Gambar 9).

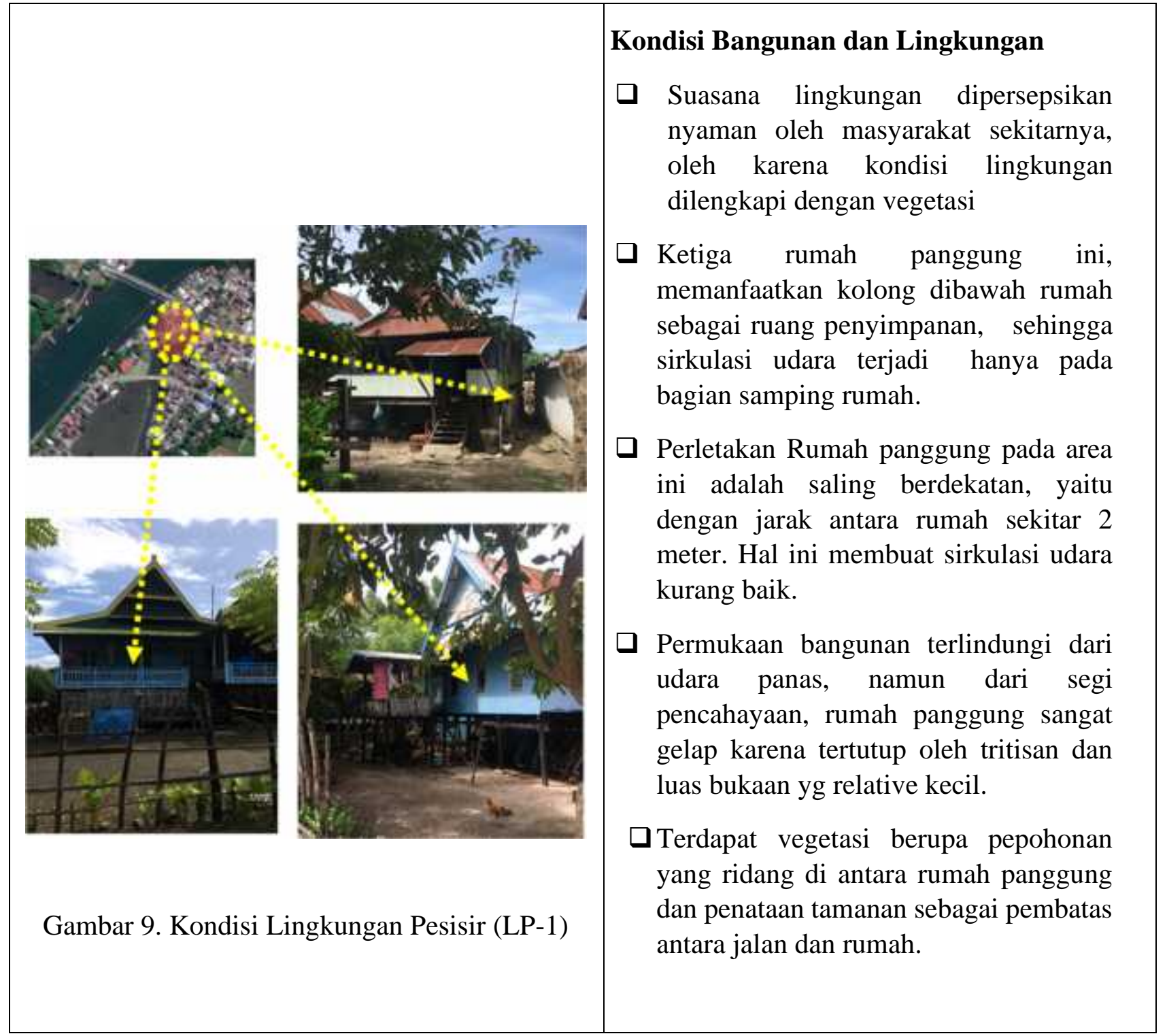

\subsection{Analisis Kondisi Lingkungan Pesisir (LP-2)}

Kondisi Lingkungan permukiman pesisir di Dusun Cikoang pada area di sekitar jembatan Sungai, dipersepsikan nyaman oleh masyarakat sekitarnya. Kenyamanan Termal terkait dengan kecepatan angin dan temperatur udara pada lingkungan sekitarnya (Gambar 10). Kenyamanan termal bukan 
hanya di lingkungan permukian pesisir, namun perlu dipertimbangkan kenyamanan di dalam rumah tinggal, sehingga penghuni dapat beraktifitas dengan baik.

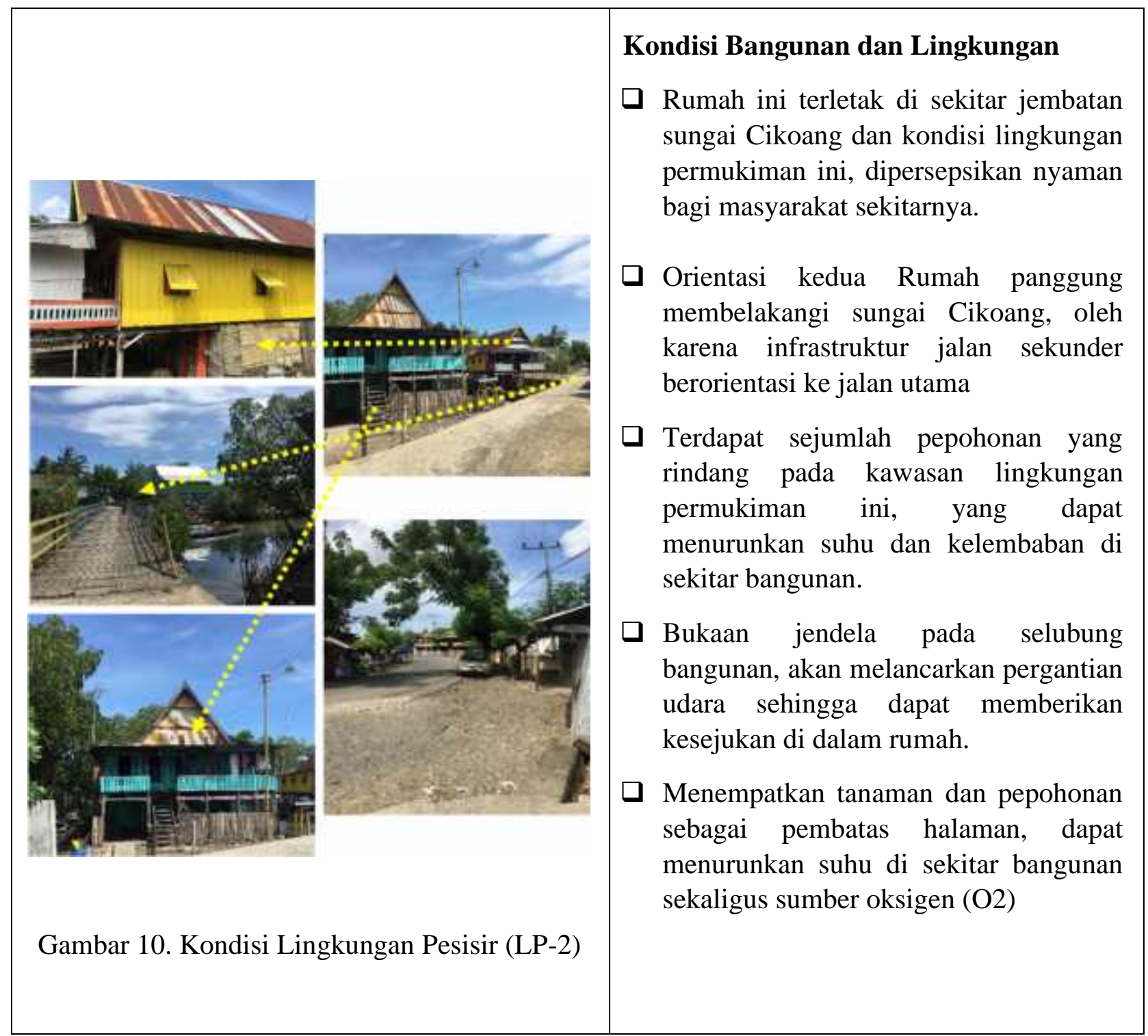

\section{Kesimpulan}

Berdasarkan kegiatan sosialisasi ini, maka Kepala Desa Cikoang beserta seluruh karyawan menyadari perlunya pemahaman tentang kondisi kenyamanan termal pada Kawasan permukiman pesisir Sungai Cikoang. Terdapat kelebihan dan kekurangan dalam penataan permukiman di Kawasan pesisir Sungai Cikoang, antara lain kurangnya vegetasi di lingkungan dan di halaman rumah sehingga kenyamanan termal belum tercapai. Beberapa saran yang ditunjukkan bahwa dengan penanaman pohon yang rindang di Kawasan pesisir, maka akan berpengaruh terhadap kecepatan angin, suhu dan kelembaban serta dapat menurunkan temperatur udara. Kenyamanan termal pada bangunan rumah tinggal di daerah pesisir sungai Cikoang, akan tercipta apabila diperhatikan desain bukaan jendela, ventilasi dan tritisan pada bangunan. Penataan lingkungan permukiman Dusun Cikoang masih perlu di tata dengan baik, oleh karena masih terdapat beberapa 
unit hunian yang saling berdekatan sehingga sirkulasi udara kurang baik. Pada rumah panggung terdapat ruang di bawah bangunan yang diistilahkan sebagai kolong rumah. Ruang ini dapat difungsikan, namun sebaiknya tidak secara keseluruhan dengan pertimbangan sirkulasi udara di ruang bawah berpengaruh terhadap ruang dalam bangunan.

\section{Ucapan Terima Kasih}

Terimakasih atas dukungan kepala Desa Cikoang beserta seluruh karyawan kantor Desa Cikoang yang telah membantu kami dalam melaksanakan pengabdian masyarakat, sehingga sosialisasi ini dapat terlaksana dengan baik. Terima kasih kepada Tim Laboratory Based Education (LBE) Fakultas Teknik Universitas Hasanuddin, oleh karena tim kami telah diberi peluang untuk melakukan pengabdian masyarakat di Dusun Cikoang Desa Cikoang Kecamatan Mangarabombang Kabupaten Takalar.

\section{Daftar Pustaka}

Permen PU, (2001). Perumahan Rakyat Republik Indonesia tentang Penetapan Garis Sempadan Sungai dan Garis Sempadan Danau.

Silas, Johan, (1985). Buku Ajar (Buku 1 dan Buku 2), Surabaya: Jurusan Arsitektur FTSP, ITS. Badan Standarisasi Nasional, (2001). Tata Cara Perancangan Sistem Ventilasi dan Pengkondisian Udara pada Bangunan Gedung, SNI 03-2396-2001.

Satwiko Prastowo, (2005). Fisika Bangunan 1, Edisi 2, Yogjakarta: Andi.

Undang Undang Republik Indonesia, (1992). Tentang Perumahan dan Permukiman, Nomor 4 Tahun 1992. 